\title{
First record of an anomalously colored franciscana dolphin, Pontoporia blainvillei
}

\author{
MARTA J. CREMER, CAMILA M. SARTORI, BEATRIZ SCHULZE, \\ RENAN L. PAITACH and ANNELISE C. HOLZ
}

\author{
Projeto Toninhas, Universidade da Região de Joinville, Caixa Postal 110, 89240-000 São Francisco do Sul, SC, Brasil
}

Manuscript received on May 29, 2013; accepted for publication on September 9, 2013

\begin{abstract}
On October 2011, a newborn franciscana dolphin with an anomalously coloration was sighted in Babitonga Bay, southern Brazil. The calf was totally white. Besides the potential mother and newborn, the group also had the presence of another adult, who always was swimming behind the pair. Both adults had the typical coloration of the species, with the back in grayish brown. The group, composed by the white franciscana calf, his pontential mother and one more adult, was reported in five occasions. The group was always in the same area where it was first recorded and showed the same position during swimming. Between first and last sighting of the white calf (113 days) the color has not changed. This is the first case of a white franciscana dolphin. This coloration has never been reported despite the high number of dead franciscanas recovered each year along the distribution of the species, resulting from accidental capture in fishing nets. This fact leads us to believe that this is a very rare characteristic for this species. We considered the possibility that this franciscana could be an albino dolphin.
\end{abstract}

Key words: anomalously coloration, Pontoporia blainvillei, franciscana dolphin, albinism, Babitonga Bay.

\section{INTRODUCTION}

Anomalous coloration is not common in marine mammals, but has been recorded in some species of cetaceans (Fertl et al. 2004). The typical coloration of the franciscana dolphin is brownish to dark gray on the back, and lighter brown to light gray below and on the lower flanks (Jefferson et al. 2008). Hundreds of dead franciscanas as a result of accidental capture in fishing nets are registered every year throughout the species range (Secchi et al. 2003). However, there are no records of anomalous coloration for the species.

On October 29, 2011, a newborn franciscana dolphin with an anomalous coloration was sighted

Correspondence to: Marta Jussara Cremer

E-mail:marta.cremer@univille.br swimming in echelon position with an adult (potentially the mother) in Babitonga Bay, southern

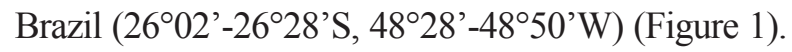
The whole body had a pink color. The calf had evidence of recent birth, such as curved dorsal fin and fetal folds, suggesting that the animal had been born within the last two or three days inside the bay. In addition to the potential mother and newborn, the group also had the presence of another adult, who was always swimming behind the pair. Both adults had the typical coloration of the species, with a grayish brown back. It was not possible to take photos on this day. On November 6, 2012, a small calf, totally white, was recorded in the same area $\left(26^{\circ} 15^{\prime} \mathrm{S}, 48^{\circ} 43^{\prime} \mathrm{W}\right)$ with a size compatible to the previously registered pinkish calf (Figure 2). 


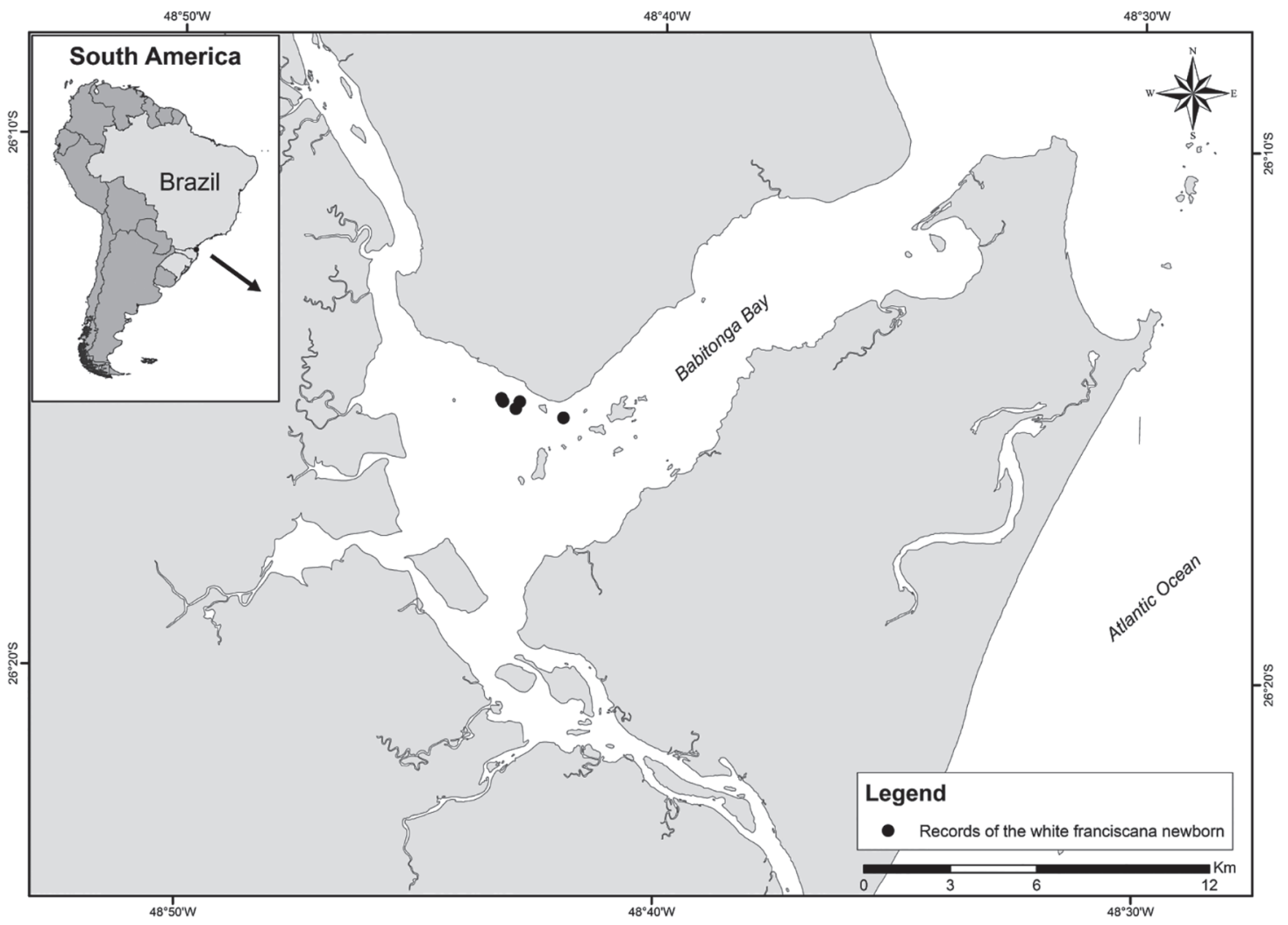

Figure 1 - Babitonga Bay, southern Brazil $\left(26^{\circ} 02^{\prime}-26^{\circ} 28^{\prime} \mathrm{S}, 48^{\circ} 28^{\prime}-48^{\circ} 50^{\prime} \mathrm{W}\right)$, and locations where the white franciscana dolphin calf was recorded.

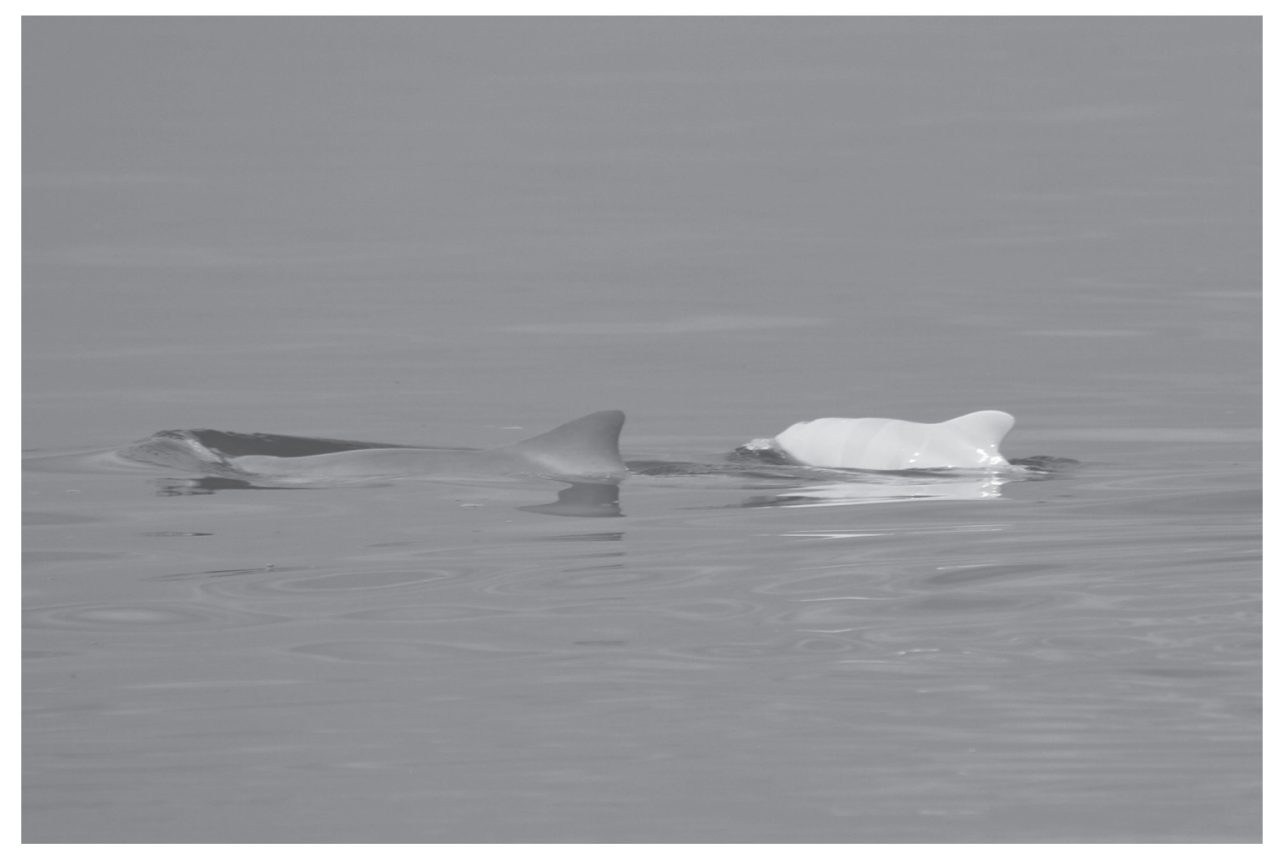

Figure 2 - A totally white franciscana newborn and his potential mother with the typical coloration of the species recorded on Babitonga Bay, south Brazil. 
Group composition was the same as described previously, but we are not sure if was the same group, especially with regards to the second adult. The calf was totally white in the dorsal region and in the head, which were the areas visible out of water (Figure 3). Just as in the first record, the calf was swimming in echelon position with an adult, potentially the mother. Unfortunately, the potential mother had no marks in the dorsal fin that could be used for individual identification. In the second sighting (November 7) we were able to identify the presence of nicks on the dorsal fin of the other adult, but we are not sure that this was the same individual recorded in the other sighting.



Figure 3 - White franciscana calf with his head out of the water and the adult that was swimming behind the pair, identified by the presence of a nick on the dorsal fin.

The group, composed by the white franciscana calf, the potential mother and one more adult was reported on six occasions (November 6, 2011; November 7, 2011; December 16, 2011; December 20, 2011; January 19, 2012; and February 27, 2012). The group was always in the same area where they were first recorded and showed the same position during swimming. During the time interval between first and last sighting of the white calf (113 days) the color had not changed.

Babitonga Bay is home to a small franciscana dolphin population, estimated at 50 individuals (Cremer and Simões-Lopes 2008). This population is monitored since 2001 for the analysis of ecological patterns. The calf reported in this work was born in the spring, which is considered the main birth period of franciscana dolphins in the region (Rosas and Monteiro-Filho 2002). All recordings of the group were made in the concentration area of this franciscana dolphin population, as described by Cremer and Simões-Lopes $(2005,2008)$.

White cetaceans are rare, but they have been reported for many species, such as the killer whale (Renner and Bell 2008) and the bottlenose dolphin (Fertl et al. 1999). Fertl et al. (2004) reviewed the occurrence of anomalously white cetaceans, indicating that this characteristic has been observed in 20 cetacean species. Recent records included Megaptera novaeangliae (Forestell et al. 2001), Stenella attenuata graffmani (Fertl et al. 2004), 
and Sotalia guianensis (Nascimento et al. 2008). However, this is the first case of a white franciscana dolphin. This coloration has never been reported despite the high number of dead franciscanas recovered each year over the species range resulting from accidental capture in fishing nets (Secchi et al. 2003). This fact leads us to believe that this is a very rare characteristic for this species.

Mammalian coloring is almost entirely the result of presence or absence of the pigment melanin in the skin, hair and eyes. Albinism is the term applied to the group of genetically determined disorders of the melanin pigmentary system. All forms of albinism are characterized by nystagmus, hypoplasia of the fovea, photophobia and decreased visual acuity (Kinnear et al. 1985). Different reasons could be attributed to changes in coloration like the one reported here. Hypo-pigmentation has been mainly attributed to a genetic hereditary deficiency involving the metabolism of melanin during prenatal development (Wagner and Mitchell 1964, Breathnock 1969), or changes in melanocyte development altering the spatial distribution or density of pigmentation across the body (Hoekstra 2006). Albinism is a condition found throughout the animal kingdom, including fishes, amphibians, reptiles, birds, and mammals (Kinnear et al. 1985).

It was not possible to see the calf's eye color, but this feature is not decisive in defining an albino. The "pink-eyed" appearance is characteristic in one type of albinism, the tyrosinase-negative oculocutaneous albinism, when iris translucency produces this form of the disorder (Kinnear et al. 1985), and many humans with albinism have blue or brown eyes. We considered the possibility that this franciscana could be an albino dolphin.

The ecological costs of this anomalous coloration were discussed by Hain and Leatherwood (1982). Viability could be reduced due to associated pathological traits such as sensory or nervous defects, anemia, low fertility, and higher susceptibility to disease. Reduced heat absorption in colder waters and increased conspicuousness to predators, also mentioned by Hain and Leatherwood (1982) were considered not highly important in this case. The mean water temperature in Babitonga Bay is high (Oliveira et al. 2006) and there are no predators, like sharks and killer whales, inside the bay. However, we considered that exposure of skin and eyes to sunlight could be a big problem, favoring the development of cancer and accentuating vision problems, similar to those reported for humans (Kinnear et al. 1985).

Despite the continuous monitoring of the franciscana population in the bay after the first sighting of the white calf, he was no longer observed. One possibility is that the pair has left the bay, but we consider that this is the least likely hypothesis. Over more than ten years of studies of this population we have not found evidence that there are constant movements in and out of the bay (Cremer and Simões-Lopes 2005, 2008). Telemetry-linked studies, recently developed in this area, reinforce the hypothesis that franciscanas in Babitonga Bay are highly resident (M.J. Cremer, unpublished data). Another possibility is that the animal is still in the area and was not observed, considering the difficulties for franciscana observations. We cannot discard the hypothesis that this calf has died as a consequence of reduced viability related to this abnormality, or that the potential mother and this calf died as a consequence of accidental capture in fishing nets, commonly used inside the bay (Pinheiro and Cremer 2003).

\section{ACKNOWLEDGMENTS}

The Projeto Toninhas/UNIVILLE is sponsored by Petrobras, through Programa Petrobras Ambiental, which enabled this work. We thank Projeto Toninhas' staff for executive management and assistance in the field.

\section{RESUMO}

Em outubro de 2011, um filhote recém-nascido de toninha com uma coloração anormal foi avistado na 
Baía da Babitonga, sul do Brasil. O filhote era totalmente branco. Além da potencial mãe e do filhote, o grupo tinha a presença de mais um adulto que estava sempre nadando atrás da dupla. Ambos os adultos tinham a coloração típica da espécie, com o dorso em um tom marrom-acinzentado. O grupo, composto pelo filhote branco de toninha, sua potencial mãe e mais um adulto foi registrado em cinco ocasiões. O grupo estava sempre na mesma área onde foi avistado pela primeira vez e apresentou a mesma formação durante a natação. Entre a primeira e a última avistagem do filhote branco (113 dias), a coloração não se alterou. Este é o primeiro caso de uma toninha branca. Esta coloração nunca foi reportada apesar do grande número de toninhas mortas recuperadas a cada ano ao longo da distribuição da espécie resultante de captura acidental em redes de pesca. Este fato nos leva a acreditar que esta é uma característica muito rara para a espécie. Nós consideramos a possibilidade de que esta toninha pode ser albina.

Palavras-chave: coloração anormal, Pontoporia blainvillei, toninha, albinismo, Baía da Babitonga.

\section{REFERENCES}

BREATHNOCK AS. 1969. Normal and abnormal melanin pigmentation of skin. In: WOLMAN M (Ed), Pigments in pathology, London: Academic Press, 280 p.

CREMER MJ AND SIMÕES-LOPES PC. 2005. The occurrence of Pontoporia blainvillei (Gervais \& d'Orbigny) (Cetacea, Pontoporiidae) in an estuarine area in southern Brazil. Rev Bras Zool 22: 717-723.

CREMER MJ AND SimÕES-LoPes PC. 2008. Distribution, abundance and density estimates of franciscanas, Pontoporia blainvillei (Cetacea: Pontoporiidae), in Babitonga bay, southern Brazil. Rev Bras Zool 25: 397-402.

FERTL D, BARros NB, Rowlett RA, Estes S AND Richlen M. 2004. An update on anomalously white cetaceans, including the first account for the pantropical spotted dolphin (Stenella attenuate graffmani). Lat Am J Aquat Mamm 3: 163-166.
FERTL D, PUSSER LT AND LONG JJ. 1999. First record of an albino bottlenose dolphin (Tursiops truncatus) in the Gulf of Mexico, with a review of anomalously white cetaceans. Mar Mamm Sci 15: 227-234.

Forestell PR, PATON DA, Rodda P AND KaUfMAN GD. 2001. Observations of a hypo-pigmented humpback whale (Megaptera novaengliae) off east coast Australia: 19912000. Mem Queens1 Mus 47: 437-450.

HAIN JHW AND LEATHERWOOD S. 1982. Two sightings of white pilot whales, Globicephala melaena, and summarized records of anomalously white cetaceans. J Mamm 63: 338-343.

HoEKSTRA HE. 2006. Genetics, development and evolution of adaptive pigmentation in vertebrates. Heredity 97: 222-234.

JefFerson TA, WebBer MA AND PITMAn RL. 2008. Marine mammals of the world. A comprehensive guide to their identification, Sand Diego: Academic Press, 573 p.

KinNeAR PE, BARRIE JAY MD AND WitKop JR CJ. 1985. Albinism. Surv Ophthalmol 30: 75-101.

NASCIMENTO LF, SPINELli LHP, SANTOS E, QueIROZ REM, PANSARD KCA, MEDEIROS PIAP, GONDIM MA, JESUS AH, SILVA FJL AND YAMAMOTO EM. 2008. Atypical coloration in a specimen of estuarine dolphin, Sotalia guianensis, on the litoral of the state of Rio Grande do Norte, north-east Brazil. Mar Biodiv Rec 1: 1-2.

OliveIra TMN, TUREK CR, BASSFEld J, FARIA J, BRASIL $\mathrm{K}$ AND TORRENS BMO. 2006. Integridade ambiental da Baía da Babitonga: características físico-químicas, microbiológicas e ecotoxicidade. In: CREMER MJ ET AL. (Eds), Diagnóstico ambiental da Baía da Babitonga, Joinville: Editora da Univille, Joinville, Brasil, p. 20-80.

PINHEIRO L AND CREMER MJ. 2003. Etnoecologia e captura acidental de golfinhos (Cetacea: Pontoporiidae e Delphinidae) na Baía da Babitonga, Santa Catarina. Desenvolv Meio Amb 8: 69-75.

RENNER M AND BELL K. 2008. A white killer whale in the Central Aleutians. Arctic 61: 102-104.

RosAs FCW AND MONTEIRO-FILHO ELA. 2002. Reproductive parameters of Pontoporia blainvillei (Cetacea, Pontoporiidae), on the coast of São Paulo and Paraná states, Brazil. Mammalia 66: 231-245.

SeCChi E, DANILEWICZ D AND OTT PH. 2003. Applying the phylogeographic concept to identify franciscana dolphin stocks: implications to meet management objectives. J Cetacean Res Manage 5: 61-68.

WAGNER RP AND MITCHELL HK. 1964. Genetics and metabolism, $2^{\text {nd }}$ ed., New York: J Wiley \& Sons, 673 p. 
